\title{
Basson slapped down by committee
}

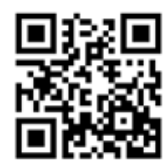

The High Court-approved recusal application by apartheid-era chemical and biological weapons expert Dr Wouter Basson to the two-person Medical and Dental Professions Board Professional Conduct Committee was turned down flat last month.

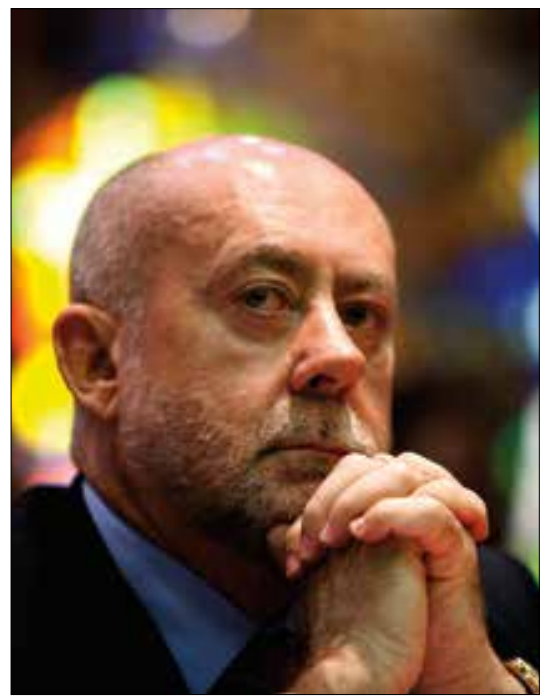

Dr Wouter Basson.

The latest twist in the 14-year-long hearing, beset by dysfunction in prosecuting the case by the umbrella complainant body, the Health Professions Council of South Africa (HPCSA), technical postponements and legally skilful delaying High Court applications, may yet deliver more surprises before argument in mitigation of sentence continues on 28 May. Basson's veteran legal counsel, Jaap Cilliers, SC, submitted that committee chairperson Prof. Jannie Hugo and his deputy Prof. Eddie Mhlanga showed a 'clear bias' in failing to disassociate themselves from petitions calling for the strongest possible censure of Basson, drawn up by the South African Medical Association (SAMA) and the Rural Doctors' Association of South Africa (RUDASA) and filed in aggravation of sentence.

Cilliers marched out of the committee's December sentencing hearing after Hugo refused to disclose whether he was a member of either organisation, successfully securing a High Court order compelling him to hear an application calling for his and Mhlanga's recusal. Both highly respected clinicians admitted in papers submitted to the High Court that they were members of the organisations but inactive in management, adding that they would never have contemplated signing such petitions, given the inherent conflict of interest. Cilliers, who was pivotal in securing President Jacob
Zuma's rape charge acquittal in 2006 and has represented several right-wingers in other high-profile court cases, told the 13 March recusal hearing that Hugo's refusal to disclose his membership of the medical bodies was 'bizarre'. At no stage had Hugo 'disassociated himself' from the stance of these bodies, he contended.

Cilliers argued that the committee granted the complainant (the HPCSA) more than a year to 'search the world' for an expert willing to support its stance that Basson acted unethically, yet when he asked for a postponement to probe Prof. Hugo's involvement with the medical bodies, the committee insisted on continuing the hearing in Basson's absence, a 'clear indication' of bias. Cilliers called this as 'an absolute travesty of justice and a disregard of all rules pertaining to a fair trial', and later labelled the proceedings a 'Laurel and Hardy show'. He devoted a large part of his argument to the committee's stance that any medical doctor who joined the defence force in the 1980s was unethical and unprofessional.

\section{Hugo responds to recusal application}

Hugo responded that the petition was initiated by the People's Health Movement, 
not SAMA or RUDASA, who nevertheless supported it, like many other organisations. His and Mhlanga's association with the two bodies related to their academic and professional work and had no bearing on the matter before them. Basson thus failed to support his claim that the committee was biased, with a vested interest in the outcome. 'We need to assure Dr Basson that we are acutely aware of our duties in this matter and that he will continue to experience a fair trial', he added.

In December 2013 the committee found Basson guilty of unprofessional and unethical conduct in that he co-ordinated large-scale production of illegal psychoactive drugs (including Ecstasy), armed mortars with teargas and provided military operatives with disorientating substances to make illegal cross-border kidnappings easier. He also made cyanide capsules available to apartheid-era military spies so that they could commit suicide if captured.

One HPCSA witness said that the Durbanville heart surgeon was unrepentant and failed to show 'that he even reflected on the possibility' that he had violated medical ethics, while Hugo said in judgment that medical ethics were 'especially important' in times of war and conflict. Basson had defiled the 'unique and sacred position' of trust in doctors by society that impelled them to stay true to the ethical values of 'beneficence, non-maleficence, justice and autonomy'. Basic medical ethics had not changed since the time of the offences, Hugo stressed.

\section{Hugo responded that the petition} was initiated by the People's Health Movement, not SAMA or RUDASA, who nevertheless supported it, like many other organisations. His and Mhlanga's association with the two bodies related to their academic and professional work and had no bearing on the matter before them.

\section{Enormous hearing costs hiked by both sides}

While the HPCSA will not reveal the cost of the 14-year hearing (in particular Basson's costs), it has dragged on six times as long as late former police commissioner Jackie Selebi's corruption trial (late 2009 - 2012), which cost R17 million. The State is footing both bills. Basson has continued to practise between the protracted hearings.
The hearing has helped highlight the general dysfunctionality of the HPCSA, in this case via several belated legal submissions, many containing errors that continually gave the upper hand to Basson's lawyers over the years, dragging out proceedings and pushing up costs. National health minister Dr Aaron Motsoaledi last month ordered a full investigation into HPCSA maladministration and the fitness of the body's managers to lead it. Izindaba has over the past decade repeatedly highlighted HPCSA dysfunction, including the drinking habits of a former president, internal corruption in the registration of foreign-qualified doctors (some inappropriately qualified and let loose on an unsuspecting public), and its accreditation and monitoring of training hospitals.

An independent investigation panel will be chaired by the head of the University of Cape Town's Department of Medicine, Prof. Bongani Mayosi, and is due to report back to Motsoaledi at the end of next month (May).

\section{Chris Bateman}

chrisb@hmpg.co.za

S Afr Med J 2015;105(3):250-251

DOI:10.7196/SAMJ.9601 